\title{
Understanding the Interrelationship Between Global Terrorist Attacks and the Citizen's Wellbeing: The Complexity of Terrorism
}

\author{
Aida Huerta-Barrientosa, Pablo Padilla Longoria ${ }^{a}$
}

\begin{abstract}
Terrorism is a global phenomenon that over the last 44 years more than 140,000 terrorist events have been carried out. In the period from 1970-2001, the five countries with the largest number of terrorist attacks were Colombia, Peru, El Salvador, United Kingdom, and India. On the other hand, in the post-2001 context, the five countries with the largest number of terrorist attacks were Iraq, Pakistan, Afghanistan, India, and Thailand. One method for measuring in an aggregate way, how many people have suffered under terrorist attacks at national level is to analyze the correlation between some national wellbeing indicators and the number of terrorist attacks. The aim of this study is to analyze empirically the correlation between the global terrorist attacks and the countries wellbeing indicators. Five indicators show a strong relationship with the number of terrorist attacks in the case of the four most attacked countries in the post-2001 context. The authors consider that their findings can support the design of new strategies for preventing terrorist activities taking into account certain socio-economic and political drivers. The authors conclude that as such drivers are socio-complex, so it is necessary to adopt the complex adaptive system (CAS) approach to provide a new way of thinking about terrorism.
\end{abstract}

\section{Keywords}

Terrorist attacks, national wellbeing, global governance, corruption, drugs

There is not a consensual definition of terrorism that encompasses attacks, whether against civilian noncombatants or armed military (Ranstorp 2007). One of the most widely used definitions of terrorism is provided by the U.S. Department of State. According to the definition included in the Title 22 of the U.S. Code, Section 2656f(d), "terrorism is premeditated, politically motivated violence perpetrated against noncombatant targets by subnational groups and clandestine agents, usually intended to influence an audience". The term "noncombatant" includes civilians and the military personnel who are unarmed or not on duty (U.S. Department of State 2004). While the Federal Bureau of Investigation (FBI) defines terrorism as "the unlawful use of force or violence against persons or property to intimidate or coerce a government, the civilian population, or any segment thereof, in furtherance of political or social objectives". Both definitions of terrorism share a common theme: The use of violence intended to influence a course of action that furthers a political or social goal.

aNational Autonomous University of Mexico, Mexico City, Mexico

\section{Correspondent Author:}

Aida Huerta-Barrientos, Department of Operations Research, Faculty of Engineering, National Autonomous University of Mexico, 04510, Mexico City, Mexico 
Definitions of terrorism used in the social sciences also vary as to whether terrorism includes attacks against only "noncombatant" targets or whether terrorism is also a tactic of warfare used by sub-national groups against all citizens of a state, whether civilian or military, including attacks against an "armed" military (Ranstorp 2007). According to the United Nations Office on Drugs and Crime (UNODC), if terrorism is defined strictly in terms of attacks on non-military targets, a number of attacks in military installations and soldiers residences could not be included in the statistics. In the academia arena, a definition of terrorism was proposed initially by Schmid and Jongman (1988) and referred to an anxiety-inspiring method of repeated violent action, employed by (semi-) clandestine individual, group, or state actors, for idiosyncratic, criminal, or political reasons, whereby-in contrast to assassination-the direct targets of violence are not the main targets. Schmid and Jongman pointed out that the immediate human victims of violence are generally chosen randomly (targets of opportunity) or selectively (representative or symbolic targets) from a target population, and serve as message generators. Also, threat-and violence-is based on communication processes among terrorist (organization), (imperiled) victims, and main target (audiences), turning it into a target of terror, a target of demands, or a target of attention, depending on whether intimidation, coercion, or propaganda is primarily sought. While there is not a formal definition, the fact is that terrorism, in terms of violence perpetrated against noncombatant targets, is actually considered a global phenomenon (Institute for Economics \& Peace 2014) that continues to pose a major threat to international peace and security and undermines the core values of the United Nations (UNODC 2016). Since 1970, more than 140,000 terrorist events have occurred in 207 different countries using mainly explosives, bombs, dynamite, and firearms, causing around 310,000 civilians killed. In addition to the devastating human cost of terrorism, in terms of lives lost or permanently altered, terrorist acts aim to destabilize governments and undermine economic and social development, so addressing this threat is that much more difficult given the complex and constantly evolving dynamics of terrorist activity (UNODC 2016). Although terrorism has been present in social life for decades, only after the World Trade Center Attacks of September 11, 2001, did the topic gain new significance as a sociopolitical phenomenon and as a method of warfare (Vos Fellman, Bar-Yam, and Minai 2015). The authors propose that measuring the correlation between socio-economic and political indicators and the terrorism activity, they can estimate some drivers that need attention paid by governments in order to prevent terrorism. The aim of this study is to analyze empirically the correlation between the global terrorist attacks and the wellbeing of countries in terms of narcotrafic, religious diversity, voice and accountability, political stability and absence of violence, government effectiveness, regulatory quality, rule of law, and control of corruption indicators. This study is based on data from the Global Terrorism Database (GTD), produced by the National Consortium for the Study of Terrorism and Responses to Terrorism (START), the Afghanistan Opium Survey 2015 (UNODC 2015), the Religious Diversity Index (RDI 2015) (Johnson and Grim 2013), and the dataset Worldwide Governance Indicators (WGI 2015). GTD is an open-source database including information on terrorist events around the world from 1970 through 2014 (with additional annual updates planned for the future) that includes systematic data on domestic as well as transnational and international terrorist incidents that have occurred during this time period (GTD 2015). Afghanistan Opium Survey 2015 was implemented by the Ministry of Counter Narcotics (MCN) of Afghanistan in collaboration with the UNODC. The survey results provide a detailed picture of the outcome of the current year's opium season and together with data from previous years, 
enabling the identification of medium-and-long-term trends in the evolution of the illicit drug problem in Afghanistan. The Religious Diversity Index (RDI 2015), scores for countries, regions, and the world based on the shares of eight major world religions (Buddhism, Christianity, folk or traditional religions, Hinduism, Islam, Judaism, other religions considered as a group, and the religiously unaffiliated). It is a version of the Herfindahl-Hirschman Index, which is used in various fields to measure the degree of concentration of human or biological populations as well as organizations. The Worldwide Governance Indicators (WGI 2015) are a research dataset summarizing the view on the quality of governance provided by a large number of enterprise, citizen, and expert survey respondents in industrial and developing countries. These data are gathered from a number of survey institutes, think tanks, non-government organizations, international organizations, and private sector firms. The indicators are aggregated in six dimensions of governance: voice and accountability, political stability and absence of violence/terrorism, government effectiveness, regulatory quality, rule of law, and control of corruption. Details on the underlying data source, the aggregation method, and the interpretation of the indicators, can be found in the WGI methodology (Kaufmann, Kraay, and Mastruzzi 2010).

This paper is prepared as follows: The analysis of the countries and cities most impacted by terrorist groups in the period from 1970 to 2014 is presented in Section 2. The main interrelationships between terrorism attacks and national wellbeing indicators in the post-2001 context are evaluated in Section 3. The dynamic evolution of terrorist groups is characterized in Section 4. The actual international counter-terrorism efforts are analyzed and the development of public policy for preventing effectively terrorism based on CAS (complex adaptive system) perspective is suggested in Section 5. Finally, the concluding remarks are presented in Section 6.

\section{THE COUNTRIES AND CITIES MOST IMPACTED BY TERRORIST GROUPS FROM 1970 TO 2014}

On the one hand, in the period from 1970 to 2001, the five countries most impacted by terrorist groups were Colombia (6,548 attacks), Peru (6,029 attacks), El Salvador (5,320 attacks), United Kingdom (4,324 attacks), and India (3,459 attacks), followed by Spain (3,021 attacks), Turkey (2,545 attacks), United States (2,430 attacks), France (2,298 attacks), and Chile (2,278 attacks). On the other hand, in the period from 2002 to 2014, the 10 countries ranked at the top of terrorist incidents were Iraq (15,851 incidents), Pakistan (9,606 incidents), Afghanistan (7,613 incidents), India (5,610 incidents), Thailand (2,829 incidents), Philippines (2,690 incidents), Somalia (2,299 incidents), Nigeria (2,158 incidents), Yemen (1,804 incidents), and Russia (1,480 incidents). The countries most impacted by terrorist activity in the period under study, from 1970 to 2014, were Colombia, India, Algeria, Sri Lanka, Philippines, Pakistan, and West Bank and Gaza Strip. It means that the terrorism activity has continued in these countries from almost four decades. At the level of cities, the five cities with the largest number of civilians killed by terrorist attacks in the period from 1970 to 2001 were New York City (2,812 deaths), Beirut (1,591 deaths), Karachi (1,512 deaths), Belfast (1,279 deaths), and Gikoro (1,180 deaths). The most frequent weapons used by terrorist groups from 1970 to 2001 were explosive, bombs, dynamite, firearms, incendiary, melee, and chemical. Additionally, the five cities with the largest number of civilians killed by terrorist attacks in the post-2001 period were Baghdad (16,532 fatalities), Mosul (2,549 fatalities), Tikrit (2,290 fatalities), Mogadishu (2,054 fatalities), Karachi (1,850 fatalities), followed by Baqubah (1,673 fatalities), Kirkuk (1,366 fatalities), Maiduguri (1,348 fatalities), Peshawar (1,309 fatalities), Quetta (1,266 fatalities). Explosive, bombs, and dynamite 
remained the preferred weapons by terrorists in that period.

\section{THE MAIN RELATIONSHIPS BETWEEN TERRORIST ATTACKS AND NATIONAL WELLBEING INDICATORS IN THE POST-2001 CONTEXT}

One way to estimate the influence of the socio-economic and political national conditions on the terrorism activity, and vice versa, is evaluating their interrelationships. The authors start analyzing the evolution of terrorist attacks against the evolution of the opium cultivation in the specific case of Afghanistan. Based on data from the Afghanistan Opium Survey 2015, the total area under opium poppy cultivation in Afghanistan was estimated at 224,000 hectares in 2014, a total increment of 7\% from the previous year. The vast majority (89\%) of opium cultivation took place in nine provinces in Afghanistan's southern and western regions, which include the country's most insecure provinces (UNODC 2015). A significant relationship between the opium cultivation and the terrorism activity in Afghanistan is observed. In the post-2001 context, the terrorist activity in Afghanistan increased dramatically as well as the number of hectares of opium cultivation. Hilmand remained Afghanistan's major opium-cultivating province, followed by Kandahar, Farah, and Nangarhar. In these provinces, the terrorism activity has also increased over the last decade. For example, Kandahar occurred 284 incidents, while in Farah almost 49 terrorist incidents were recorded. The Religious Diversity Index (RDI 2015) was analyzed for the four most attacked countries by terrorist groups in the 2010 year, in order to determine if religion has been a driver for terrorism in such countries. In this direction, Iraq and Afghanistan as the countries most affected by terrorist attacks in the post-2001 context have the lowest value in RDI. That means, one religion (Muslim) is predominant in these two countries. Contrary, in the case of India, the increasing intensity of terrorism activity is developed in a multi-religion context, coexisting Christians, Muslims, and Hindus (see Table 1).

The voice and accountability indicator (WGI 2015) reflects perceptions of the extent to which a country's citizens are able to participate in selecting their government, as well as freedom of expression, freedom of association, and a free media. In this case, the terrorist activity in the four countries increased from 2005 but the voice and accountability indicator just increased dramatically in 2011. So, this socio-political indicator does not correlate with the number of terrorist incidents (see Figure 1).

From the socio-political and governance aspects analyzed, five indicators show a significant relationship with the number of terrorist attacks in the case of the four most attacked countries, Iraq, Pakistan, Afghanistan, and India by terrorist in the post-2001 context. The indicators are: political stability and absence of violence/terrorism, government effectiveness, regulatory quality, rule of law, and control of corruption. The political stability and absence of violence and terrorism indicator (WGI 2015), measure perceptions of the likelihood of political instability and/or politically-motivated violence, including terrorism. This socio-political indicator shows a significant correlation with the number of terrorist incidents in the case of Pakistan and India from 2008, Afghanistan from 2011, and Iraq from 2012 (see Figure 2).

The government effectiveness indicator (WGI 2015) reflects perceptions of the quality of public services, the quality of the civil service, and the degree of its independence from political pressures, the quality of policy formulation and implementation, and the credibility of the government's commitment to such policies. This governance indicator shows a strong relationship with the number of terrorist incidents in the case of Iraq from 2002, Pakistan and India from 2008, and Afghanistan from 2011 (see Figure 3). 
Table 1. The Religious Diversity Index for the Four Most Attacked Countries by Terrorist, 2010

\begin{tabular}{lllllllll}
\hline Country & \multirow{2}{*}{ RDI } & $\begin{array}{l}\text { Percent } \\
\text { Christian }\end{array}$ & $\begin{array}{l}\text { Percent } \\
\text { Muslim }\end{array}$ & $\begin{array}{l}\text { Percent } \\
\text { unaffiliated }\end{array}$ & $\begin{array}{l}\text { Percent } \\
\text { Hindu }\end{array}$ & $\begin{array}{l}\text { Percent } \\
\text { Buddhist }\end{array}$ & $\begin{array}{l}\text { Percent folk Percent } \\
\text { religions }\end{array}$ & $\begin{array}{l}\text { Pewish } \\
\text { Jewish }\end{array}$ \\
\hline Afghanistan & .1 & $.1 \%$ & $99.7 \%$ & $.1 \%$ & $.1 \%$ & $<.1 \%$ & $<.1 \%$ & $<.1 \%$ \\
India & 4.0 & $2.5 \%$ & $14.4 \%$ & $<.1 \%$ & $79.5 \%$ & $.8 \%$ & $.5 \%$ & $<.1 \%$ \\
Iraq & .2 & $.8 \%$ & $99.0 \%$ & $.1 \%$ & $<.1 \%$ & $<.1 \%$ & $<.1 \%$ & $<.1 \%$ \\
Pakistan & .8 & $1.6 \%$ & $96.4 \%$ & $<.1 \%$ & $1.9 \%$ & $<.1 \%$ & $<.1 \%$ & $<.1 \%$ \\
\hline
\end{tabular}

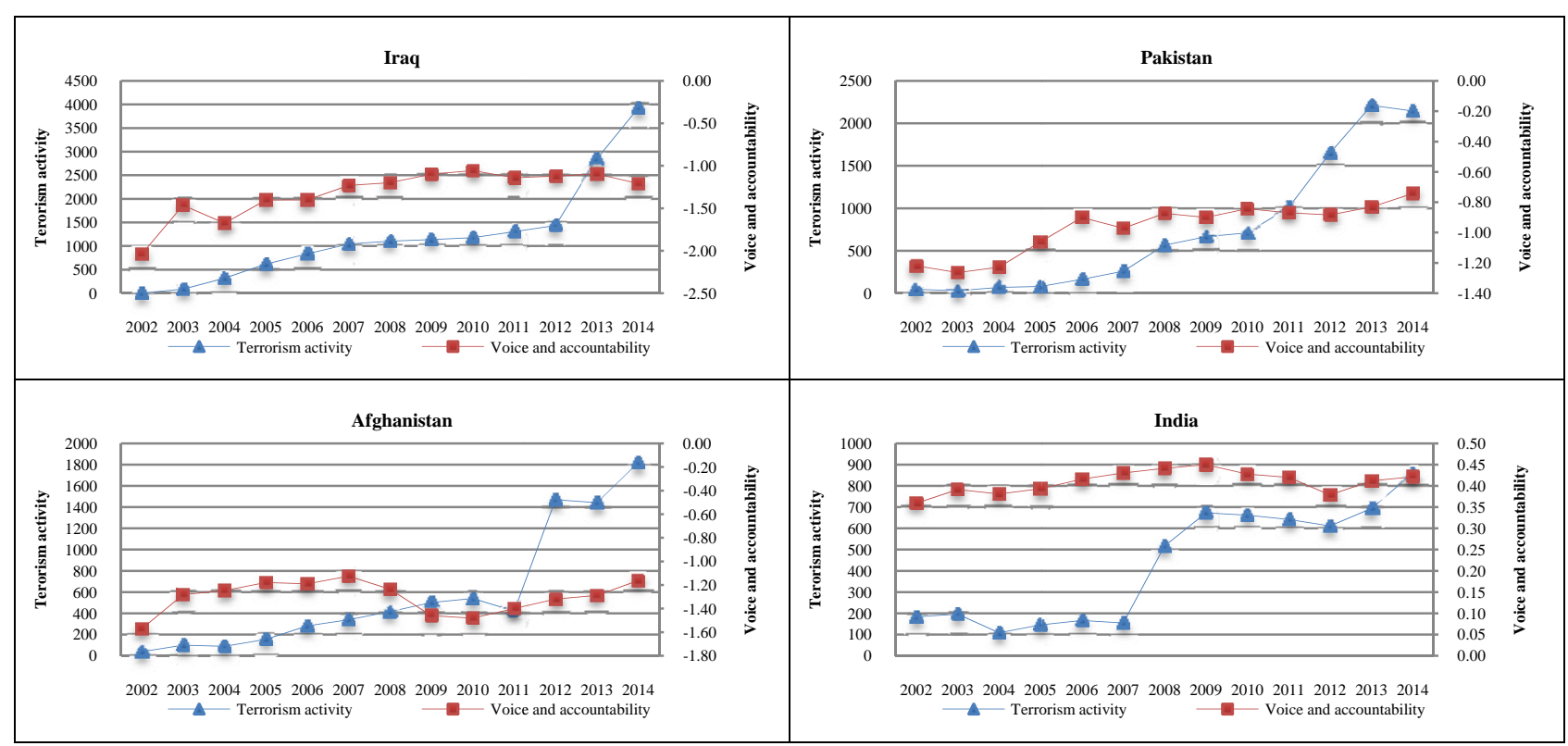

Figure 1. The Voice and Accountability Indicator for the Four Most Attacked Countries by Terrorist in the Post-2001 Context.

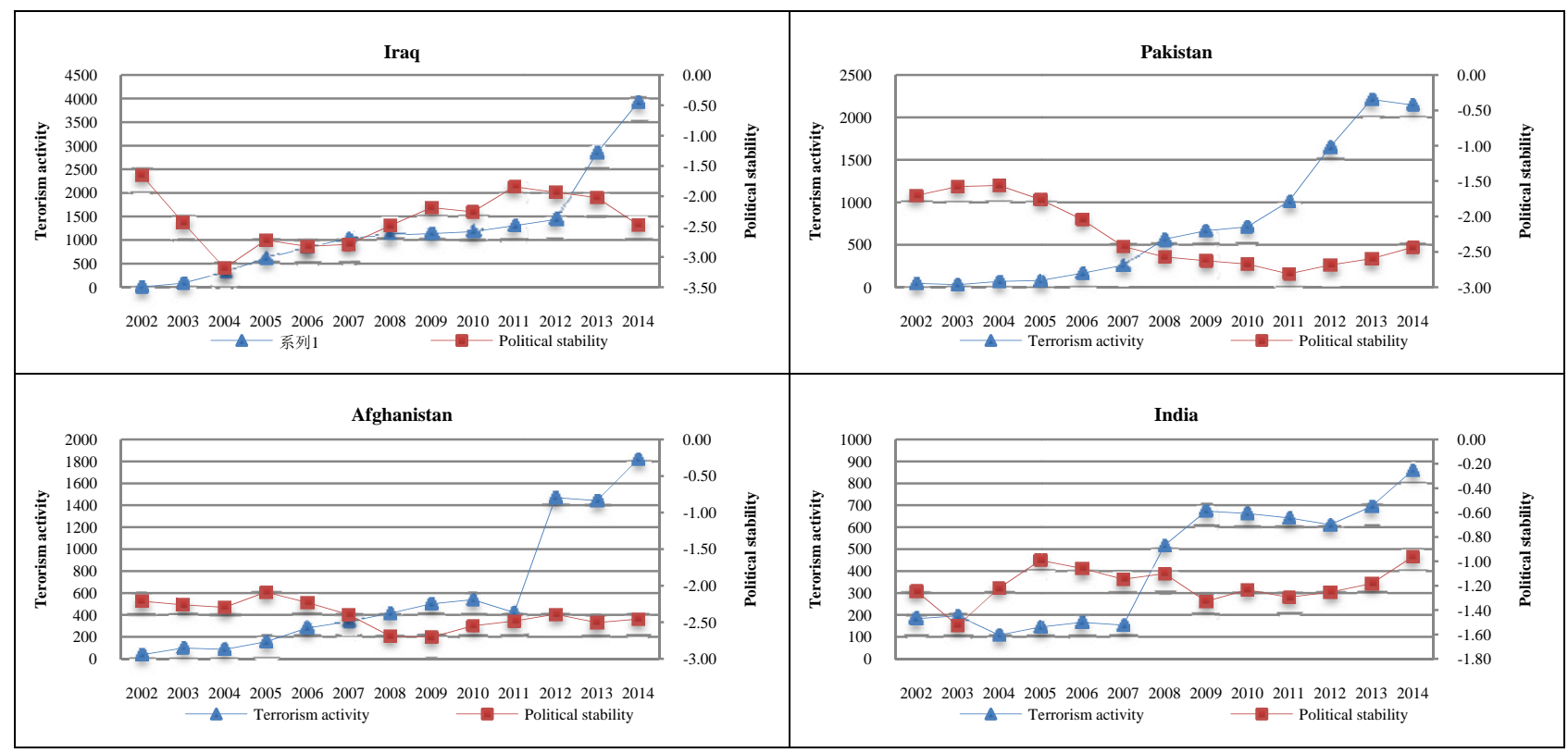

Figure 2. The Political Stability and Absence of Violence Indicator for the Four Most Attacked Countries by Terrorist in the Post-2001 Context. 


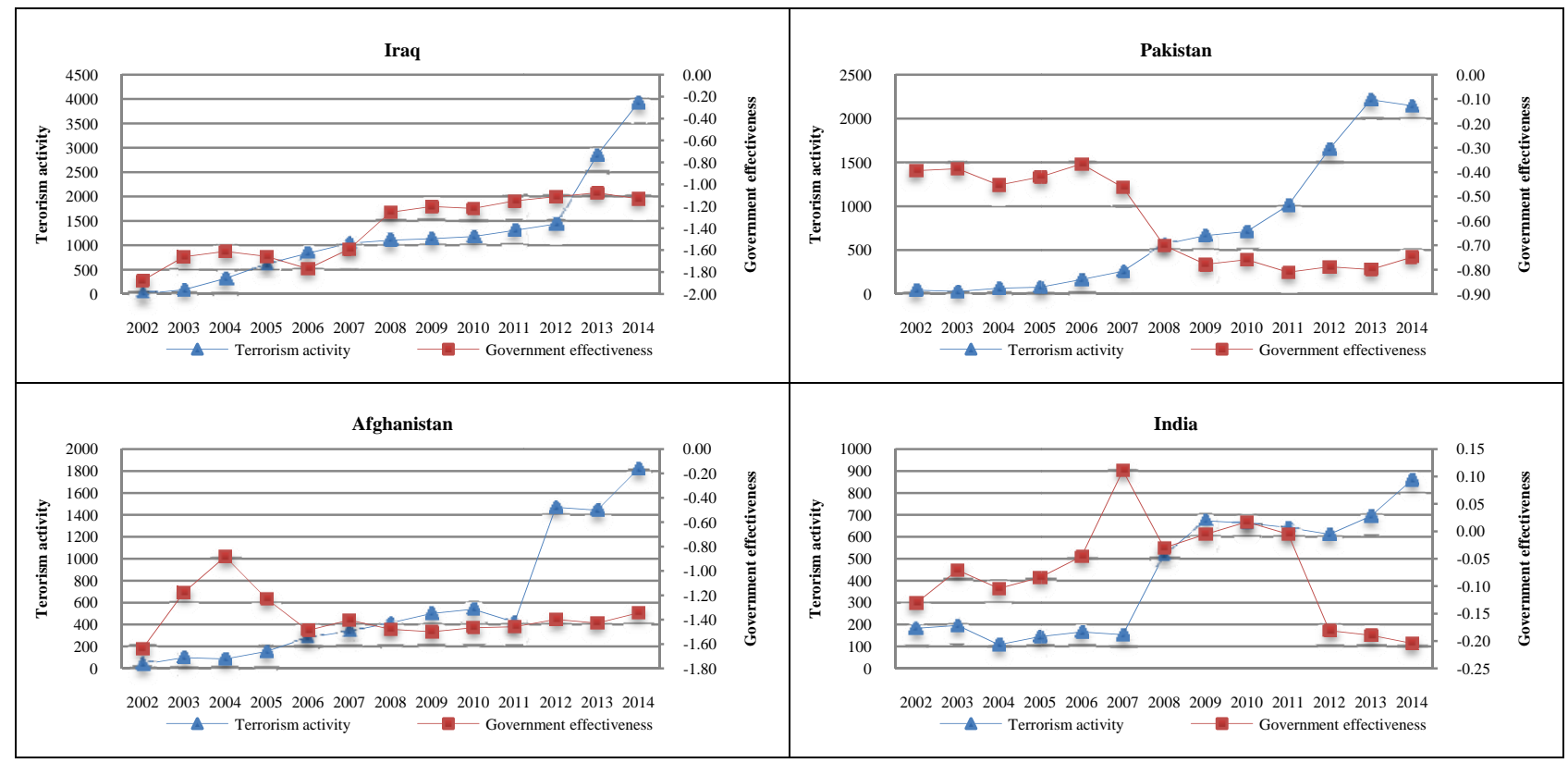

Figure 3. The Government Effectiveness Indicator for the Four Most Attacked Countries by Terrorist in the Post-2001 Context.

The regulatory quality indicator (WGI 2015) reflects perceptions of the ability of the government to formulate and implement sound policies and regulations that permit and promote private sector development. This governance indicator shows a significant correlation with the number of terrorist incidents in the case of Iraq and India from 2002 and in the case of Pakistan and Afghanistan from 2011 (see Figure 4).

The rule of law indicator (WGI 2015) reflects perceptions of the extent to which agents have confidence in and abide by the rules of society, and in particular the quality of contract enforcement, property rights, the police, and the courts, as well as the likelihood of crime and violence. This socio-political indicator shows a significant correlation with the number of terrorist incidents in the case of Pakistan, India, Afghanistan, and Iraq from 2002 (see Figure 5).

The control of corruption indicator (WGI 2015) reflects perceptions of the extent to which public power is exercised for private gain, including both petty and grand forms of corruption, as well as "capture" of the state by elites and private interests. This socio-political indicator shows a strong relationship with the number of terrorist incidents in the case of Pakistan and India from 2008 and Iraq and Afghanistan from 2012 (see Figure 6).

\section{DYNAMIC EVOLUTION OF TERRORIST GROUPS}

The Shining Path (Sendero Luminoso) formed in Peru in 1980 was the most active terrorist group over the period 1970-2001. It rooted in a combination of Andean mysticism, Maoism, and the world view of its leader and organizer, Abimael Guzman calling for the abolition of a national market economy, industry, the banking system, all foreign trade, and the use of currency, and for the establishment of a communal, village-oriented economy based on a barter exchange system (Gordon 1987). The Farabundo Marti National Liberation Front (FMLN) was the second major group with terrorist activity in that period. It was created in 


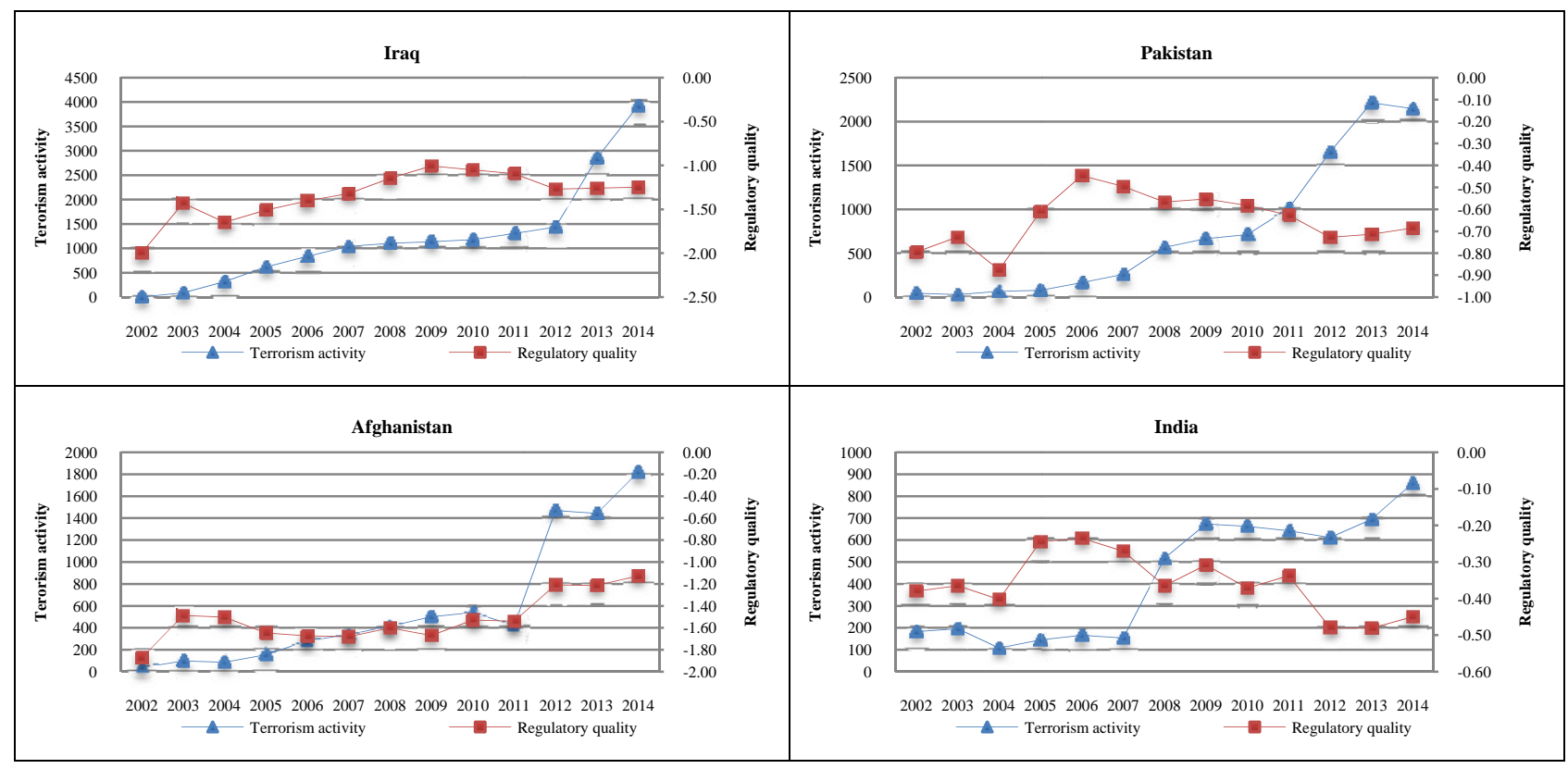

Figure 4. The Regulatory Quality Indicator for the Four Most Attacked Countries by Terrorist in the Post-2001 Context.

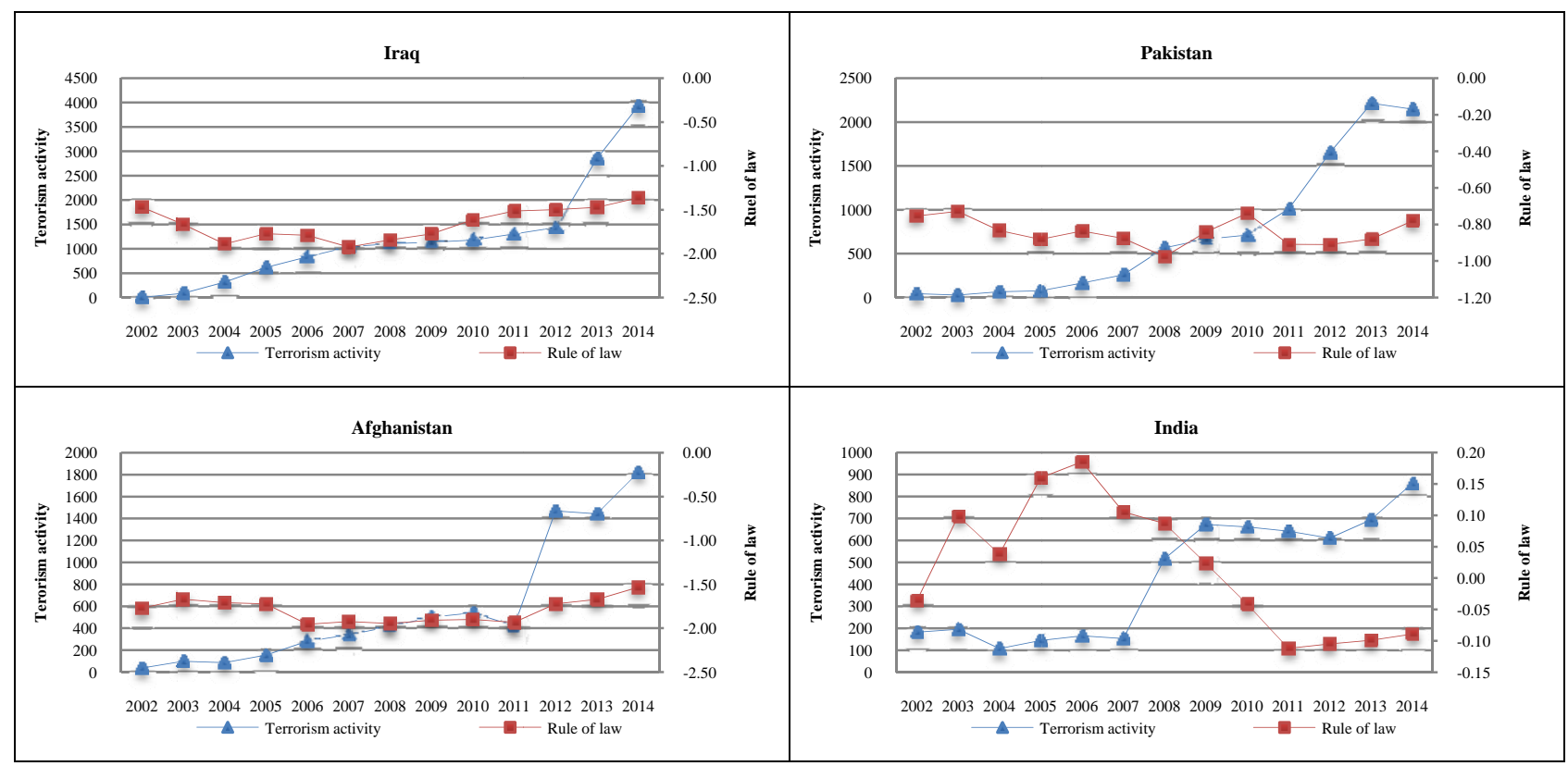

Figure 5. The Rule of Law Indicator for the Four Most Attacked Countries by Terrorist in the Post-2001 Context. 


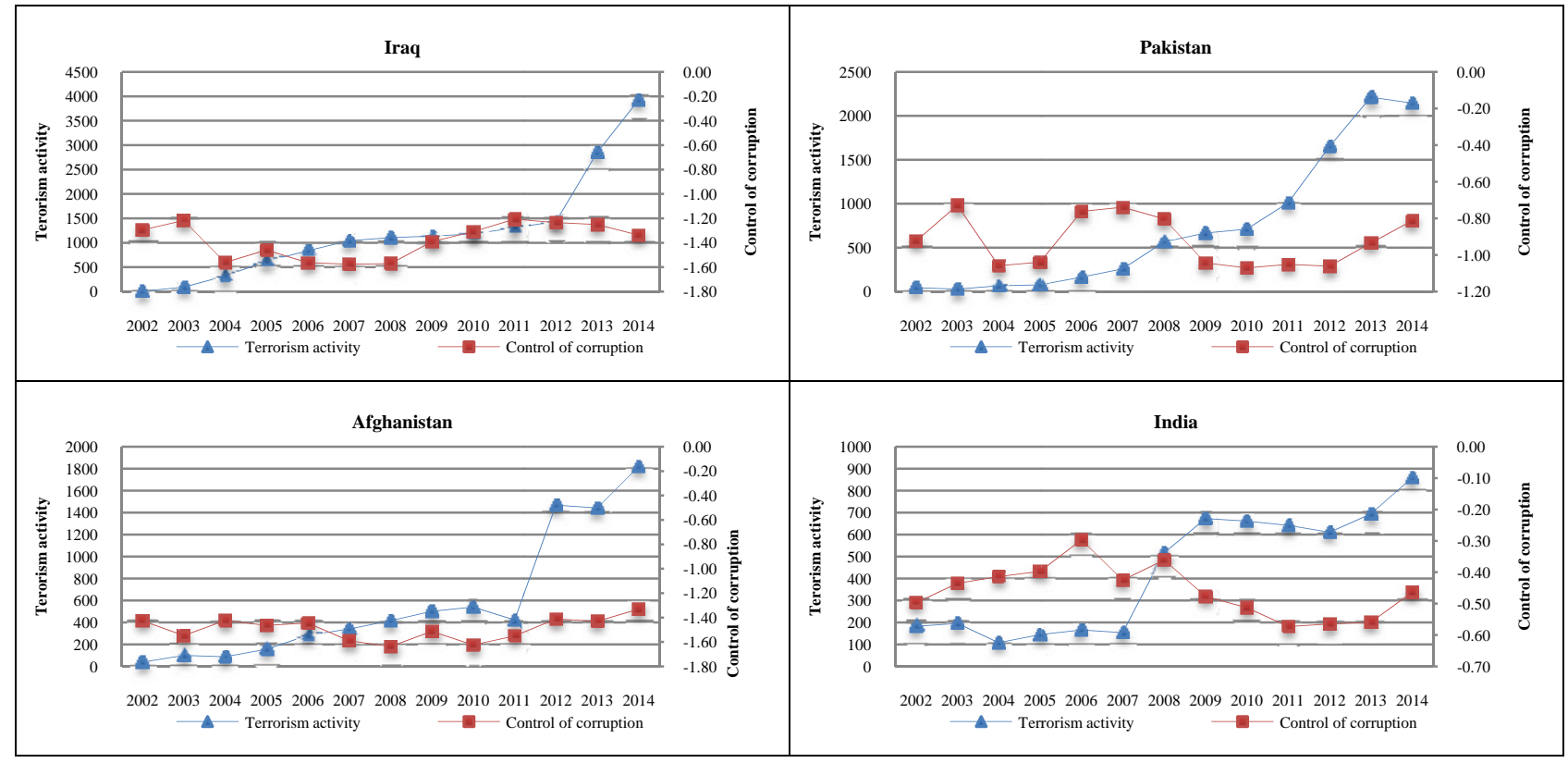

Figure 6. The Control of Corruption Indicator for the Four Most Attacked Countries by Terrorist in the Post-2001 Context.

October 1980, with the joint aim of both procuring the government's defeat as well as creating a socialist project (Martínez-Álvarez 2010). The two terrorist groups were followed in terms of their terrorist activity by the Irish Republican Army (IRA), the Basque Fatherland and Freedom (ETA), the Revolutionary Armed Forces of Colombia (FARC), and the National Liberation Army of Colombia (ELN). Contrary, in the post-2001 context, the Taliban has been the most active terrorist group followed by the Al-Shabaab, Islamic State of Iraq and the Levant (ISIL), the Communist Party of India-Maoist (CPI-Maoist), and the Boko Haram group.

\section{ANALYSIS OF THE COUNTER-TERRORISM EFFORTS EFFECTIVENESS}

Since 1963, the international community has elaborated 19 international legal instruments to prevent terrorist acts. Those instruments were developed under the auspices of the United Nations and the International Atomic Energy Agency (IAEA) and are open to participation by all member states (UNODC 2016). The legal instruments are grouped as follows: civil aviation, protection of international staff, taking of hostages, nuclear material, maritime navigation, explosive materials, terrorist bombings, financing of terrorism, and nuclear terrorism. Additionally, the United Nations General Assembly adopted the Global Counter-Terrorism Strategy on September 8, 2006, as a unique global instrument to enhance national, regional, and international efforts to counter terrorism, composed of four pillars: addressing the conditions conducive to the spread of terrorism, measures to prevent and combat terrorism, measures to build state's capacity to prevent and combat terrorism and to strengthen the role of the United Nations system in that regard, and measures to ensure respect for human rights for all and the rule of law as the fundamental basis for the fight against terrorism. Both international counter-terrorism efforts share a common theme: the prevention of terrorism. But how to effectively prevent terrorism is a major concern for all levels of government. In order to 
effectively prevent terrorism, based on the insights of this study, the authors recommend that governments need to recognize the terrorism as a social phenomenon motivated by political-ideological drivers that emerge from the lowest values in political stability and absence of violence/terrorism, government effectiveness, regulatory quality, rule of law, and control of corruption indicators. So, the authors suggest counter-terrorism policymaking must be based on the improvement of global socio-political conditions. But these conditions are complex and multifactorial, and their motivations are constantly changing, so the traditional counter-terrorism efforts such as international efforts are infeasible in affecting life satisfaction of citizens. So, it is necessary to adopt the CAS perspective for developing public policy in order to prevent effectively terrorist activity (Elliot and Kiel 2004; Bousquet 2012). A CAS by definition is "a system in which large networks of components with no central control and simple rules of operation give rise to complex collective behavior, sophisticated information processing, and adaptation via learning or evolution” (Mitchell 2009). In this case, public policy needs to be seen as affecting a complex evolving system, the networks formed by terrorist groups at global level, which cannot be controlled, but while it cannot be controlled, it can be influenced, and policy makers, have to continually think how to work with evolutionary pressures, and try to guide those pressures toward desirable ends (Colander and Kupers 2014), the minimization of the terrorist activity.

\section{CONCLUSIONS}

In this study, the authors analyzed empirically the correlation between the global terrorist attacks and national wellbeing indicators in the post-2001 context. The political stability and absence of violence/terrorism, government effectiveness, regulatory quality, rule of law, and control of corruption indicators showed a strong relationship with terrorism activity in the case of Iraq, Pakistan, Afghanistan, and India by terrorist. Additionally, in the specific case of Afghanistan, the terrorist activity increased dramatically as well as the number of hectares of opium cultivation after 2001. Related to the effect of religious diversity on terrorist activity, it is carried out in one-religion as well as in multi-religion contexts. The perceptions of the extent to which a country's citizens are able to participate in selecting their government, as well as freedom of expression, freedom of association, and a free media do not correlate with the number of terrorist incidents. The authors consider that their findings can support the design of new strategies for preventing terrorist activities taking into account certain socio-economic and political drivers. As such drivers are complex and multifactorial, and their motivations, financing, methods of attack, and choice of target are constantly changing, so the traditional counter-terrorism efforts such as international efforts are infeasible to respond to collective crises generated by the terrorist attacks affecting life satisfaction in public spaces. In conclusion, it is necessary to adopt the CAS approach to provide a new way of thinking about terrorism.

\section{Acknowledgements}

The authors are grateful to National Consortium for the Study of Terrorism and Responses to Terrorism (START), a United States Department of Homeland Security Center of Excellence based at the University of Maryland (2015). Global Terrorism Database (Data file). Retrieved from (http://www.start.umd.edu/gtd).

\section{References}

Bousquet, A. 2012. “Complexity Theory and the War on Terror: Understanding the Self-organising Dynamics of Leaders Jihad.” Journal of International Relations and Development 15(3):345-369.

Colander, D. and R. Kupers. 2014. Complexity and the Art of Public Policy: Solving Society's Problems From the Bottom up. New Jersey: Princeton University Press.

Elliot, E. and L. D. Kiel. 2004. “A Complex Systems Approach 
for Developing Public Policy Toward Terrorism: An Agent Based Approach.” Chaos, Solitons and Fractals 20(1):63-68.

Gordon, M. 1987. The Shining Path and Peruvian Terrorism. Santa Monica, CA: RAND Corporation.

GTD (Global Terrorism Database). 2015. Overview of the GTD. Retrieved (http://www.start.umd.edu/gtd/about/).

Institute for Economics \& Peace. 2014. Global Terrorism Index 2014. Measuring and Understanding the Impact of Terrorism. Retrieved (http://www.economicsandpeace.org).

Johnson, T. M. and B. J. Grim. 2013. Religious Diversity. The World's Religions in Figures: An Introduction to International Religious Demography. New York: Wiley-Blackwell. Pp. 93-108.

Kaufmann, D., A. Kraay, and M. Mastruzzi. 2010. "The Worldwide Governance Indicators: A Summary of Methodology, Data and Analytical Issues.” World Bank Policy Research Working Paper No. 5430. Retrieved (http://papers.ssrn.com/sol3/papers.cfm?abstract_id=16821 30).

Martín-Álvarez, A. 2010. "From Revolutionary War to Democratic Revolution: The Farabundo Martí National Liberation Front (FMLN) in El Salvador.” Berghof Conflict Research. Retrieved (http://www.berghof-foundation.org/ fileadmin/redaktion/Publications/Papers/Transitions_Series/ transitions9_elsalvador.pdf).

Mitchell, M. 2009. Complexity: A Guided Tour. Oxford: Oxford University Press.

Ranstorp, M. 2007. Mapping Terrorism Research. State of the Art, Gaps and Future Direction. New York: Routledge Taylor \& Francis Group.

RDI (Religious Diversity Index). 2015. Table: Religious Diversity Index Scores by Country. Retrieved (http://www. pewforum.org/2014/04/04/religious-diversity-index-scoresby-country/).

Schmid, A. P. and A. J. Jongman. 1988. Political Terrorism: A New Guide to Actors, Authors, Concepts, Databases,
Theories, and Literature. New Brunswick and London: Transaction Publishers.

U.S. Department of State. 2004. Patterns of Global Terrorism 2003. Office of the Coordinator for Counterterrorism.

- 2007. Country Reports on Terrorism. April 30, Office of the Coordinator for Counterterrorism.

UNODC (United Nations Office on Drugs and Crime). 2015. Afghanistan Opium Survey 2015: Executive Summary. Retrieved (https://www.unodc.org/documents/crop-monitor ing/Afghanistan/Afg_Executive_summary_2015_final.pdf).

- 2016. The United Nations Office on Drugs and Crime and Terrorism Prevention. Retrieved (https://www.unodc. org/ unodc/en/terrorism/index.html).

Vos Fellman, P., Y. Bar-Yam, and A. Minai. 2015. Conflict and Compelxity. Countering Terrorism, Insurgency, Ethnic and Regional Violence. New York: Springer.

WGI (Worldwide Governance Indicators). 2015. The Worldwide Governance Indicators. Retrieved (http://www. govindicators.org).

\section{Bios}

Aida Huerta-Barrientos, Ph.D. in Operations Research from National Autonomous University of Mexico, associate professor of the Graduate Department of Operations Research, Faculty of Engineering, National Autonomous University of Mexico, Mexico City, Mexico; research fields: social complexity, social movements, terrorism, complex adaptive systems, sustainability, and telecommunications.

Pablo Padilla Longoria, Ph.D. in CIMS from New York University, USA, researcher at the Department of Mathematics and Mechanics, IIMAS, National Autonomous University of Mexico, Mexico City, Mexico; research fields: molecular biology, medicine, engineering, genetics, applied mathematics, social science, economics, and evolutionary biology. 